\title{
Effect of flavored water on the morphological and chemical composition of human dental enamel microestructure in vitro
}

DOI: $10.46932 / \operatorname{sfjdv2n2-047}$

Received in: january 1st, 2020

Accepted in: March 30th, 2020

\section{Gómez B. Francisco}

Odontólogo Facultad de Odontología Universidad Nacional de La Plata.

Calle 50 entre Av. 1 y calle 115. La Plata Bs. As. Argentina.

E-mail: od.gomezbravo@gmail.com

\section{Guzmán María P.}

Odontóloga Facultad de Odontología Universidad Nacional de La Plata.

Calle 50 entre Av. 1 y calle 115. La Plata Bs. As. Argentina.

E-mail: mpia.guzman.2@gmail.com

\section{Papasodaro Jimena}

Odontóloga Facultad de Odontología Universidad Nacional de La Plata.

Calle 50 entre Av. 1 y calle 115. La Plata Bs. As. Argentina.

E-mail: jimepapa@yahoo.com.ar

\section{Procopio R. Melina M.}

Odontóloga Facultad de Odontología Universidad Nacional de La Plata.

Calle 50 entre Av. 1 y calle 115. La Plata Bs. As. Argentina

E-mail: melina.p.r@hotmail.com

\section{Saldías Alejandro J.}

Odontólogo Facultad de Odontología Universidad Nacional de La Plata.

Calle 50 entre Av. 1 y calle 115. La Plata Bs. As. Argentina.

E-mail: alejandrosaldias83@ hotmail.com

\section{Ogas Cintia S.}

Odontóloga Facultad de Odontología

Universidad Nacional de La Plata. Calle 50 entre Av. 1 y calle 115. La Plata Bs. As. Argentina.

E-mail: cintiaogas1983@gmail.com

\section{Motta Guillermo M.}

Odontólogo Facultad de Odontología

Universidad Nacional de La Plata. Calle 50 entre Av. 1 y calle 115. La Plata Bs. As. Argentina.

E-mail: martinmotta21@ @otmail.com

\section{De Landaburu Rosario}

Odontóloga Facultad de Odontología

Universidad Nacional de La Plata. Calle 50 entre Av. 1 y calle 115. La Plata Bs. As. Argentina.

E-mail: rdelandaburu@gmail.com 


\begin{abstract}
There is a remarkable interest in the dental area about the effect produced by the acidic agents contained in commercial non-alcoholic drinks on dental enamel due to their ability to produce caries or erosive lesions. The objective was to characterize the morphological and the chemical alterations of the adamantine structure exposed to the action of a flavored water. Human dental crowns sectioned in the buccolingual direction were embedded in polymer. Flat and highly polished surfaces were obtained by wear with descending granulation sandpaper. Observations and chemical analyses were performed on radial enamel before and after exposure to the beverage, at the ESEM FEI QUANTA 200-EDS (SeMFiLIMF. FI- UNLP). For the morphological description, the etching patterns of the enamel were considered. The chemical elements sodium, magnesium, chlorine, and the calcium/phosphorus ratio were studied. The samples were immersed in $100 \mathrm{ml}$ of a flavored water for 12 minutes. At the ESEM, the prisms presented different patterns of acid etching, which may affect the core or the profile. The chemical composition showed variations according to the area, before and after the treatment. Although the studied elements were present in the healthy enamel, both in the radial and in the Hunter Schreger bands, the percentage values were different. In the bands, sodium and magnesium increased while chlorine decreased. After the action of the flavored water, sodium and magnesium increased even more and the chlorine dropped markedly. A significant difference was found in $\mathrm{Ca} / \mathrm{P}$ ratio before and after treatment. The beverage used contains acid agents in its composition that produce loss of minerals from the adamantine tissue. We conclude that the exposure of tooth enamel to flavored water produces demineralization compatible with erosion lesions.
\end{abstract}

Key words: dental enamel- demineralization- soft drinks

\title{
1 INTRODUCTION
}

Dental enamel is the tissue most exposed to demineralization phenomena due to the action of acids, causing the appearance of lesions, which can progress, affecting the dentin and pulp. These acids come mainly from streptococcus in dental plaque. Colony counting methods allow determining the degree of colonization produced by Streptococcus mutans, being very useful to identify the population at high risk of dental caries (Ojeda-Garcés, 2013). Romero and Iniesta (2021) mention some factors that contribute to increasing the risk of cavities such as enamel hypoplasia, poor nutritional status, medications that reduce saliva or contain sugar, as well as conditions of oral dysphagia or reflux, when exposing the teeth to acid gastric content.

However, not all demineralization lesions of tooth enamel are associated with bacteria. Eating foods with low $\mathrm{pH}$ causes different degrees of erosion (Lussi 1993). Various investigations warn about the effects of fruit juices and carbonated drinks on the enamel of deciduous and permanent teeth (Pimentel Lopes, 2013). Sabel et al (2012) report that enamel responds to demineralization with lesions of different depths and this is related to the chemical composition. They established a correlation between the carbon content and the depth of the lesions: when carbon was in a higher proportion in healthy enamel, the depth of the lesions was greater. This research also determined that the lesion was deeper when the degree of porosity of the enamel was higher (Sabel, 2012). It is known, through observation under electron 
microscopy, that the exposure of enamel to acid solutions produces a honeycomb-shaped etching pattern, where the center of the prism (central zone) is more affected than its periphery due to selective mineral loss (Tyler, 1976).

Another study (Yin-Lin, 2014), evaluated the erosive potential of different soft drinks, finding that the $\mathrm{pH}$ values were below the critical $\mathrm{pH}$ of enamel hydroxyapatite. In addition, it was determined that beverages with citric acid and ascorbic acid in their composition, presented the highest acid titration. According to Torres et al. (2016) non-carbonated beverages, such as fruit juices or high-sugar beverages, contain organic acids such as citrus (orange), tartaric (grapes), maleic (apple), and ascorbic (vitamin C), all of which contain a low $\mathrm{pH}$.

Tooth enamel is an acellular tissue that contains between 80 and $90 \%$ of its volume of hydroxyapatite crystals and the remaining $10-20 \%$ is generally composed of organic protein material and water. (Tyler, 1976). Various chemical components have been identified in this tissue such as $\mathrm{P}, \mathrm{Ca}, \mathrm{Mg}$, Zn, Pb, Co, F, I, Fe, Al, Se (Mariel Cárdenas, 2010). In the permanent dentition, the calcium/phosphorus ratio is constant in its thickness, except for the tendency to lower values on the surface, possibly due to the formation of calcium-deficient apatite (Weatherell, 1974). The enamel microstructure presents a very complex organization since the prisms do not follow a rectilinear path from their origin in the enameldentine junction to the external surface. Under the optical microscope, intercrossing of the prisms can be distinguished occupying the inner two thirds of the enamel thickness, giving rise to the Hunter Schreger bands (HSB), while in the outer third, the prisms are arranged parallel to each other forming the so-called radial enamel.

The aim of this work was to characterize the morphological and chemical aspects of enamel with Hunter Schreger bands and radial enamel, exposed to flavored water in vitro.

\section{METHODOLOGY}

In this study, longitudinal sections of human dental crowns obtained with the informed consent of the patient were used. These were embedded in acrylic resin and worn flat. Water-based sandpaper with progressive granulation (particle 600, 1200, 1500 y 2000) were used and finally a cloth and rotating instruments to give high shine. The samples were washed with alcohol, then ultrasound for 5 minutes and dried.

Samples were soaked for 12 minute in $100 \mathrm{ml}$ of a commercially available orange flavored water, removed, and washed with water. Metallized with gold was done for observation and chemical analysis using an ESEM FEI QUANTA 200 with an EDS probe belonging to the Electron Microscopy and 
Microanalysis Service of the Physical Metallurgy Research Laboratory. (SeMFi-LIMF. FI- UNLP). The working conditions were high vacuum at $20 \mathrm{kV}$ in an area of $100 \mu 2$.

Acid etching patterns are considered for the morphological description of enamel by the action of the drink (Silverstone, 1975).

The elemental chemical analysis were performed for calcium $(\mathrm{Ca})$, phosphorus $(\mathrm{P})$, sodium $(\mathrm{Na})$, magnesium $(\mathrm{Mg})$, chlorine $(\mathrm{Cl})$ and the $\mathrm{Ca} / \mathrm{P}$ ratio. Recordings were made on the radial enamel and with Hunter-Schreger bands (HSB) before and after the action of the drink.

The ANOVA test with Bonferroni multiple comparisons was used. The accepted error $\alpha$ was 0.05 .

\section{RESULTS}

\subsection{MORPHOLOGICAL ASPECTS}

The micrographs of the healthy enamel show a characteristic arrangement of the prisms in each zone, being parallel to each other in the radial enamel and presenting cross-linking in bundles in the HSB enamel. (Fig. 1). In this latter, prisms can be distinguished in transverse and longitudinal section arranged alternately.

After the action of the drink, in the radial enamel, numerous small porosities are observed while the contours of the prisms were slightly defined. In the longitudinal sections of the prisms, the interprismatic space takes on an irregular appearance. In cross sections, the prisms presented two patterns: in several samples a depression of the center of the prism was observed, maintaining high contours (Fig. 2A), while in others, the pattern was reversed, that is, the centers remained elevated and the contours depressed (Fig. 2B). These alterations correspond to the type I and II patterns of enamel acid etching, respectively.

Figure 1. Micrograph of healthy enamel. RE: Radial enamel. HSB Hunter Schreger bands. SEM x 180

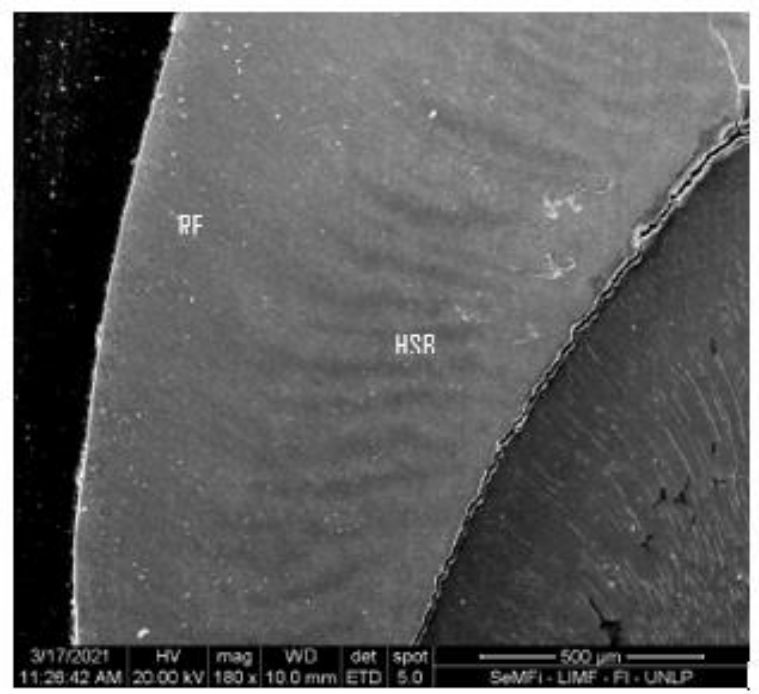


Figure 2. Micrograph of the enamel treated with the drink. A and B enamel HSB. Prisms are seen in cross-section with affected centers (A) and with affected contours (B). SEM x 1000
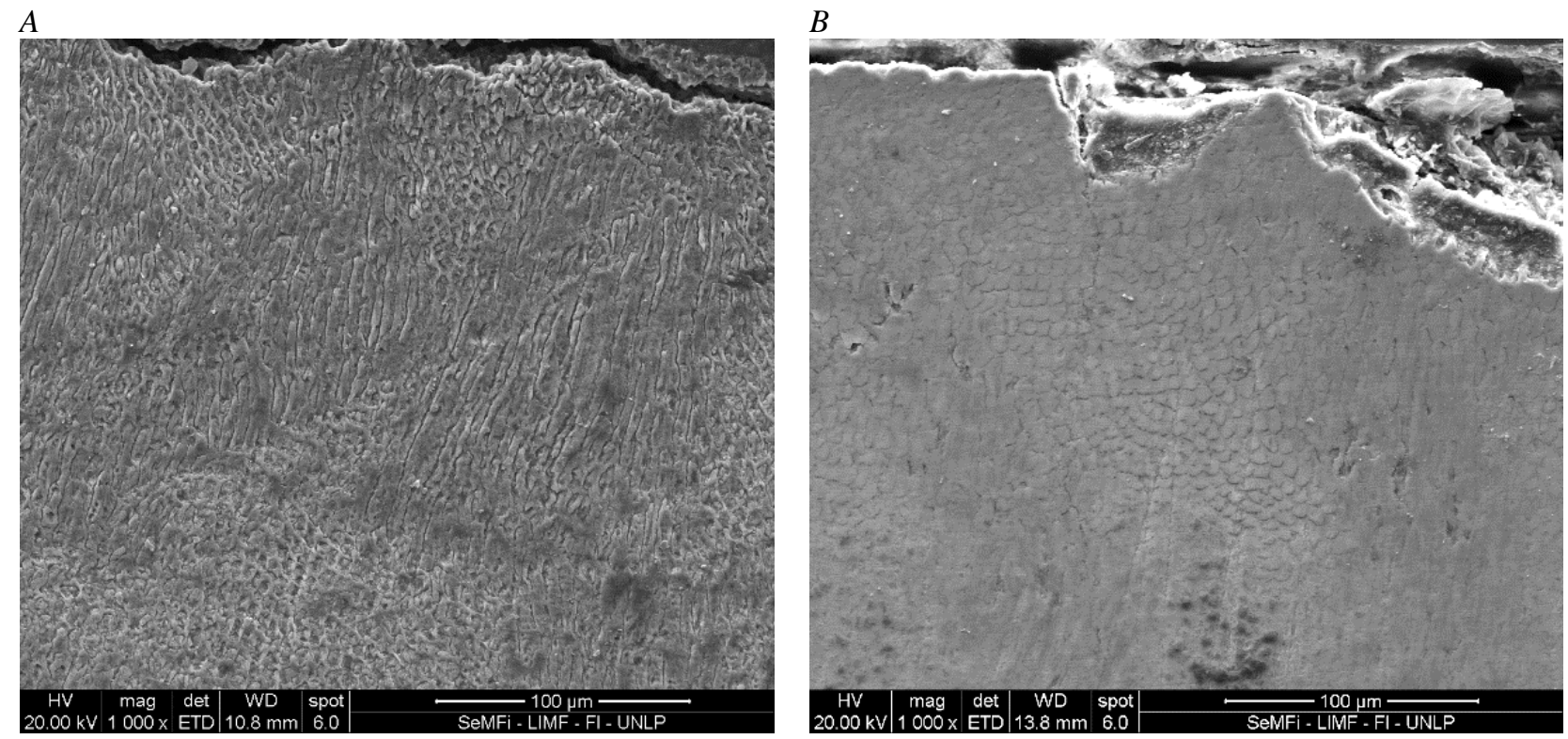

\subsection{ELEMENTARY CHEMICAL COMPOSITION (ECC)}

Energy dispersive analyses (EDAX) of healthy and treated enamel were performed and observed pronounced peaks for calcium and phosphorus; in addition, other elements such as sodium, magnesium and chlorine were detected. (Fig. 3). The relative values (weight \%) of the qualitative and quantitative analysis of healthy and treated tissue are shown in Table I.

In healthy enamel, sodium is found in a higher percentage in BHS enamel. After treatment with the drink, increased in HSB enamel (Na: $0.88 \%$ ) in relation to healthy enamel (Na: $0.70 \%)$. The difference was significant, however, no significant difference was found in the percentage of sodium between healthy and treated radial enamel. Regarding magnesium, no significant difference was found in healthy radial enamel and HSB, however, after immersion in the drink, the percentage was higher in HSB (Mg: 0.29\%) than in healthy enamel. (Mg: 0.23). Chlorine is found in a higher proportion both in healthy radial enamel and in that treated with the drink, the difference being significant (Fig. 4).

The $\mathrm{Ca} / \mathrm{P}$ ratio did not show a significant difference between healthy, as well as in treated enamel. However, after immersion in the drink, the $\mathrm{Ca} / \mathrm{P}$ ratio decreased in radial enamel and in treated HSB $(\mathrm{Ca} / \mathrm{P}: 2.0)$ relative to healthy enamel $(\mathrm{Ca} / \mathrm{P}: 2.1)$ and difference was significant (Fig. 4).

In summary, although the elements studied are present in healthy enamel, both in radial and in Hunter Schreger bands, the percentage values were different. Sodium and magnesium are found in a higher proportion in HSB, while the proportion of chlorine was higher in radial enamel. After the action of the flavored water, in HSB, sodium and magnesium increased even more and chlorine decreased markedly. The calcium/phosphorus ratio decreased in both areas after treatment. 
Figure 3. Energy dispersive spectra (EDS) of healthy and drink-treated enamel. A and B healthy enamel. C and D enamel treated with the drink

\section{A. HEALTHY RADIAL ENAMEL}

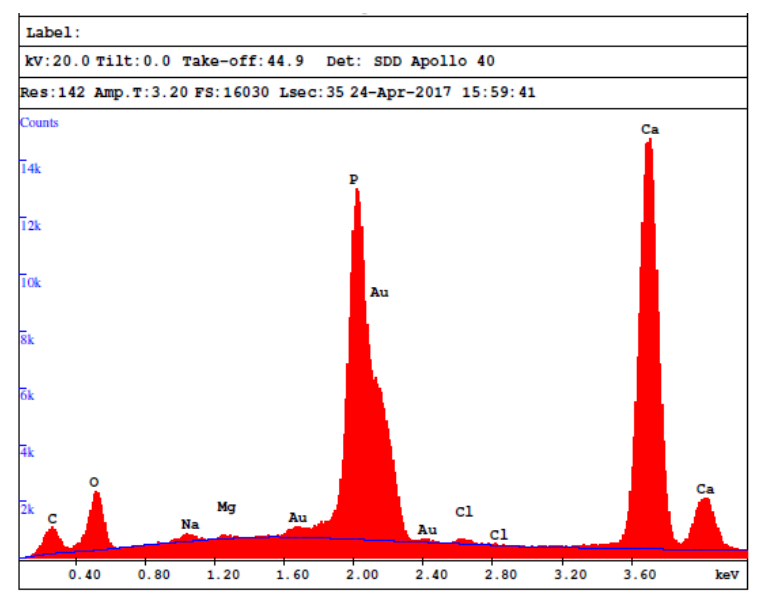

\section{TREATED RADIAL ENAMEL}

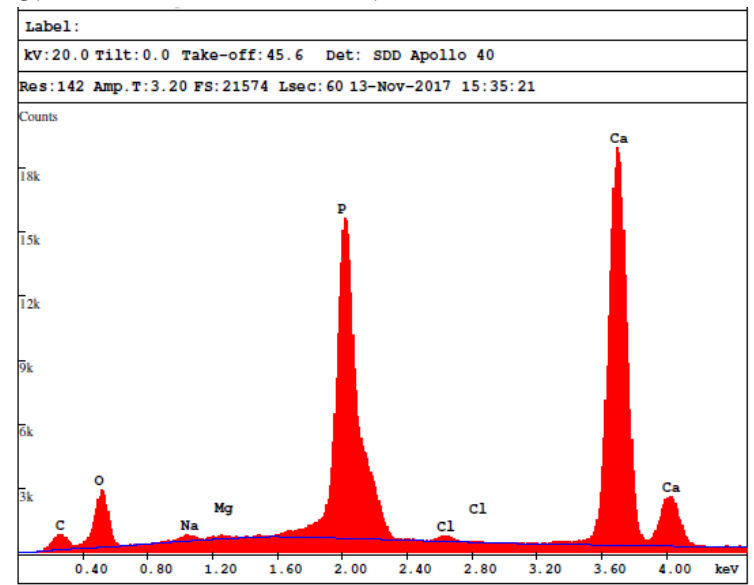

\section{B. HEALTHY HSB ENAMEL}

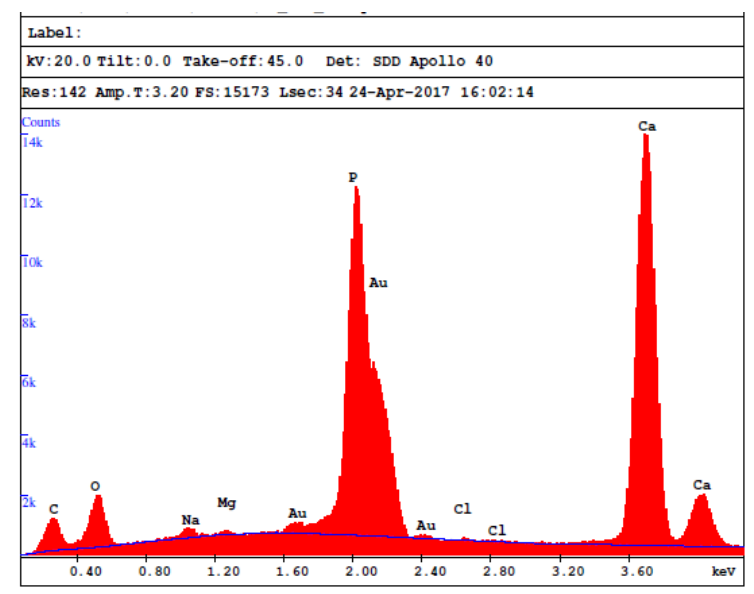

\section{TREATED HSB ENAMEL}

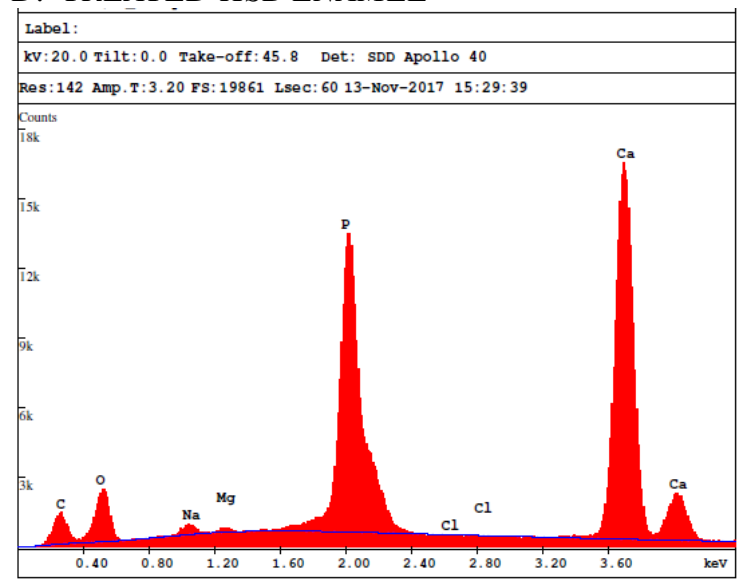

Table I. Elemental chemical analysis of tooth enamel. Values expressed in weight percentage

\begin{tabular}{|c|c|c|c|c|c|c|c|}
\hline & & $\mathrm{Na}$ & $\mathrm{Mg}$ & $\mathrm{P}$ & $\mathrm{Cl}$ & $\mathrm{Ca}$ & $\mathrm{Ca} / \mathrm{P}$ \\
\hline \multirow{4}{*}{$\begin{array}{l}\text { ESMALTE } \\
\text { SANO } \\
\end{array}$} & Radial & $0,54^{\mathrm{a}}$ & 0,19 & 18,14 & $0,38^{\text {ac }}$ & 38,36 & $2,11^{\mathrm{a}}$ \\
\hline & & $\pm 0,09$ & $\pm 0,07$ & $\pm 0,51$ & $\pm 0,09$ & $\pm 1,15$ & $\pm 0,03$ \\
\hline & BHS & $0,70^{\mathrm{ab}}$ & $0,23^{\mathrm{b}}$ & 18,05 & $0,14^{\mathrm{a}}$ & 38,14 & $2,11^{\mathrm{b}}$ \\
\hline & & $\pm 0,07$ & $\pm 0,05$ & $\pm 0,50$ & $\pm 0,13$ & $\pm 1,17$ & $\pm 0,02$ \\
\hline \multirow{4}{*}{$\begin{array}{l}\text { ESMALTE } \\
\text { TRATADO }\end{array}$} & Radial & 0,62 & $0,21^{\mathrm{a}}$ & 20,35 & $0,52^{\mathrm{bc}}$ & 40,70 & $2,00^{\mathrm{a}}$ \\
\hline & & $\pm 0,17$ & $\pm 0,06$ & $\pm 4,51$ & $\pm 0,13$ & $\pm 8,69$ & $\pm 0,06$ \\
\hline & BHS & $0,88^{\mathrm{b}}$ & $0,29^{\mathrm{ab}}$ & 19,56 & $0,07^{\mathrm{b}}$ & 39,39 & $2,02^{\mathrm{b}}$ \\
\hline & & $\pm 0,19$ & $\pm 0,06$ & $\pm 4,22$ & $\pm 0,07$ & $\pm 8,16$ & $\pm 0,04$ \\
\hline
\end{tabular}

a,b,c Equal letters indicate significant difference (ANOVA- Bonferroni, $\mathrm{p}<0,05$ ) 
Figure 4. Percentage mean values, deviation and error of sodium $(\mathrm{Na})$, magnesium $(\mathrm{Mg})$, chlorine $(\mathrm{Cl})$ and the calcium / phosphorus ratio $(\mathrm{Ca} / \mathrm{P})$. Healthy radial enamel, healthy HSB, treated radial and treated HSB are represented in order.

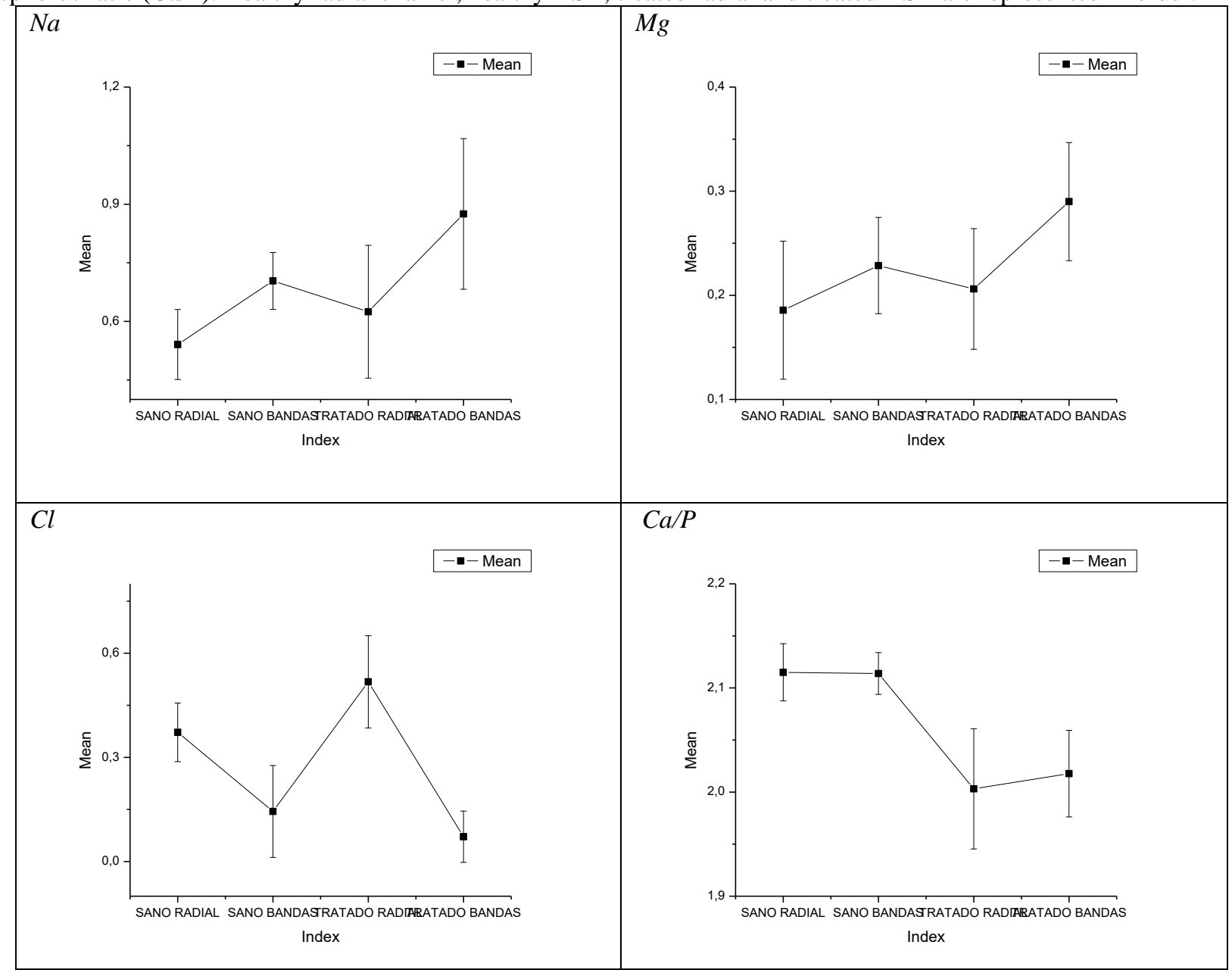

\section{DISCUSSION AND CONCLUSIONS}

In this work, we analyze the action of a flavored natural water on the microstructure of dental enamel in vitro. We consider two zones of the thickness of the adamantine tissue differentiated by the organization of the prism beams: the outermost zone where the prisms are arranged parallel to each other (radial enamel) and the inner zone, where they are organized in beams that intersect in regular layers (HSB enamel). We characterize the morphological and chemical aspects of each area.

The time in which the drink acted (12 minutes) was sufficient to produce alterations in the morphology of the prisms. In the SEM, an increase in porosity and alterations in the contours of the prisms were observed, compatible with type I and II enamel etching patterns. (Silverstone, 1975). This indicates the loss of minerals after immersion in the drink.

The flavored water used in this experiment contains, in addition to natural mineral water, citric acid and EDTA. Citric acid is a weak organic tri-carboxylic acid that is present in most fruits, especially citrus. Its molecular formula is $\mathrm{C}_{6} \mathrm{H}_{8} \mathrm{O}_{7}$. The acidity of citric acid is due to the three-carboxyl groups ($\mathrm{COOH})$ that protons can lose, forming derivatives such as citrate. Citrates are good $\mathrm{pH}$ controllers of 
acidic solutions (Muñoz Villa 2014). Citrate ions form salts with many metal ions, including calcium. Chelation is the process of joining one or more citric acid molecules and metal ions, separating them in a complex way and rendering them inactive. EDTA or ethylene-diamine-tetra-acetic acid also has a chelating action and forms stable compounds with calcium. (Segura Egea, 1997). These components are responsible for the demineralization of the adamantine tissue. Elemental analysis will determine the variation in elemental chemical composition before and after exposure to the beverage. In healthy enamel, Mariel Cárdenas et al. (2010) demonstrated that some elements vary in their concentration (g \%) from the external surface to the enamel-dentine junction. One of them is sodium, where the highest concentration was observed on the internal surface of the enamel, as demonstrated in this work. This relationship persisted after the action of the drink. Furthermore, these authors reported a higher proportion of magnesium in the internal zone, although this was not demonstrated in our analysis. However, HSB enamel presented a higher proportion of magnesium after treatment. Chlorine was found in a higher proportion in the external area (radial enamel), both in healthy enamel and in enamel treated by drinking. Therefore, demineralization did not affect the relationship of these elements in radial enamel and HSB, although the loss of calcium produced an increase in the relative percentages of sodium and magnesium and a decrease in chlorine, possibly attributed to their exit together with calcium (Table I).

We conclude that the acid components contained in flavored water produce morphological and chemical alterations compatible with erosion phenomena of dental enamel.

\section{ACKNOWLEDGMENT}

We would like to thanks the SeMFi-LIMF Microscopy Service (FI-UNLP) for the technical support and Od. Lucas de Vita for his collaboration in the translation. 


\section{REFERENCES}

1. Lussi A, Jäggi T, Schärer S (1993). The influence of different factors on in vitro enamel erosion. Caries Res., 27(5):387-393. doi:10.1159/000261569

2. Mariel Cárdenas J, Mariel Murga H, Villagrán Rueda S, Mariel Cárdenas G, Gutiérrez Cantú F, Guerrero Barrera A. (2010). Distribución de elementos químicos en el esmalte dental. Revista de Ciencias Básicas UJAT., Junio; 9 (1): 3- 116.

3. Muñoz Villa A, Sáenz Galindo A, López-López L, Cantú Sifuentes L, Barajas Bermúdez L. (2014). Ácido cítrico: compuesto interesante. Rev. Científica de la Universidad Autónoma de Coahuila, 6(12): $18-23$

4. Ojeda-Garcés Juan Carlos, Oviedo-García Eliana, Salas Luis Andrés (2013). Streptococcus mutans y caries dental. CES odontol. [Internet]., Jan [cited 2021 March 21] ; 26( 1 ): 44-56. Available from:

http://www.scielo.org.co/scielo.php?script=sci_arttext\&pid=S0120-971X2013000100005\&lng=en.

5. Pimentel Lopes De Oliveira GJ, Bomfim Da Silva MA, Chaves De Souza JA, et al. (2013). The effect of fermented milk on the deciduous enamel in the presence and absence of fluoride: in vitro study. Minerva Stomatol.62(7-8):289-294.

6. Romero Triviño Beatriz, Iniesta Albentosa Margarita (2021) Comparación de la higiene oral en niños con y sin discapacidad: importancia de la supervisión. South Florida Journal of Development, Miami, jan./mar., 2(1): 1-12. DOI https://doi.org/10.46932/sfjdv2n1-001

7. Sabel N, Robertson A, Nietzsche S, Norén JG. (2012). Demineralization of enamel in primary second molars related to properties of the enamel. The Scientific World Journal, 2012(587254).

8. Segura Egea JJ, Jiménez Rubio Manzanares A, Llamas Cadaval R, Jimenez Planas A. (1997). El ácido etilien diamino tetraacético (EDTA) y su uso en endodoncia. Endodoncia, 15(2): 90-97

9. Silverstone LM, Saxton CA, Dogon IL, Fejerskov O. (1975). Variation in the pattern of acid etching of human dental enamel examined by scanning electron microscopy. Caries Res., 9(5):373-87.

10. Torres D, Fuentes R, Bornhardt T, \& Iturriaga V (2016). Erosión dental y sus posibles factores de riesgo en niños: revisión de la literatura. Revista clínica de periodoncia, implantología y rehabilitación oral., 9(1), 19-24. https://doi.org/10.1016/j.piro.2015.09.002

11. Tyler J. (1976) A Scanning Electron Microscope Study of Factors Influencing Etch Patterns of Human Enamel. Arch Oral Biol.; 21: 765-179.

12. Weatherell JA, Robinson C, Hallsworth AS. (1974) Variations in the Chemical Composition of Human Enamel. Journal of Dental Research, 53(issue 2): 180-192.

13. Yin-Lin Wang, Chia-Chieh Chang, Chih-Wen Chi, Hao-Hueng Chang, Yu-Chih Chiang, Yueh-Chiao Chuang, Hsiao-Hua Chang, Guay-Fen Huang, Yunn-Shiuan Liao, Chun-Pin Lin. (2014). Erosive potential of soft drinks on human enamel: An in vitro study. Journal of Formosan Medical Association, 113: 850856 